\title{
On the Entry of Foreign Banks: The Jordanian Experience
}

\author{
Hadeel Yaseen ${ }^{1}$, Ghassan Omet ${ }^{2} \&$ Farah Kahmash ${ }^{3}$ \\ ${ }^{1}$ Banking and Financial Department, Applied Science Private University, Amman, Jordan \\ ${ }^{2}$ Faculty of Business, Department of Finance, The University of Jordan, Amman, Jordan \\ ${ }^{3}$ The Housing Bank, Amman, Jordan \\ Correspondence: Hadeel Yaseen, Banking and Financial Department Applied Science Private University, \\ Amman, Jordan. E-mail: h_yassin@asu.edu.jo
}

Received: March 3, 2015

Accepted: May 4, 2015

Online Published: June 25, 2015

doi:10.5539/ijef.v7n7p278

URL: http://dx.doi.org/10.5539/ijef.v7n7p278

\begin{abstract}
Relative to the numerous papers which examine the performance of banks, one of the most important key features of the evolution of foreign direct investment (FDI) flows in recent years has been the increasing proportion of FDI in the service (including banking) industry. This is why the financial economics and finance literatures include a growing number of researches that examine the effect of the entry of foreign banks on domestic bank's performance in terms of, for example, their net interest margin and competition.

This paper analyzes the issues of net interest margin and competition in the Jordanian banking system during the time period from 2000 to 2010 . In more specific terms, the paper examines the impact of the entry of foreign banks on the behavior of bank spreads and the extent of competition.

Using a panel of bank-level data, the results indicate that while well-known determinants of net interest margin are appropriate to the Jordanian scene, the effect of the entry of foreign banks on the cost of financial intermediation has not been positive. In addition, based on a non-structural measure of competition (H-statistic), the results indicate that foreign banks have not led to any significant improvement in the monopolistic competition condition that prevails in the Jordanian banking sector.
\end{abstract}

Keywords: Jordan, net interest margin, bank competition, panzar-rosse, foreign banks, financial development

\section{Introduction}

Following the classical contributions by Gurley and Shaw (1967), McKinnon (1973) and Shaw (1973), the literature that examines the relationship between financial development (financial intermediaries and financial markets) and growth has become not only extremely large, but also an important issue of debate.

The academic studies and the empirical tests of the economic growth and financial development nexus are supported by firm-level, industry-level and cross-country papers (Note 1). Following this literature, one can state that, on average, the key role and feature of finance in the economics of growth, industry growth, and in the growth of firms has developed into a stylized fact. This explains why the empirical literature also examines, for example, the determinants of financial development and whether or not there is a threshold above which financial development starts impacting growth negatively.

The fact that banks can enhance and promote economic growth, and the cost of individual bank collapse, or bank systemic crisis is higher than the failure of any other line of business, one should not be surprised that the literature has evolved and developed into a package of papers that examine a myriad of topics or issues like, for example, the determinants of the performance of banks relative to their net interest margin and return on assets, the measurement and determinants of bank efficiency, measurement of bank competition and its implications, and whether or not bank (market) discipline does exist and its implications.

Relative to what has been mentioned above about the various topics with which the banking literature deals, it is interesting to make a note that "on average, across developing countries, the shares of banks assets held by foreign banks has rise from $22 \%$ in 1996 to $39 \%$ in 2005. At the same time, foreign banks claim on developing countries, which together with the loans provided by foreign banks branches and subsidiaries including cross-border loans increased from $1 \%$ of GDP in 1996 to $26 \%$ in 2008" (Cull \& Peria, 2010). 
Proponents or supporters of the entry of foreign banks argue that they enhance and promote the competition level among local (host) banks, and improves their performance (efficiency), leads to lower financial intermediation costs (net interest margins), and promotes the growth of economy by improving the process of the allocation of resources (Jeon, 2011).

Opponents of foreign bank entry, on the other hand, argue that these (foreign) banks tend to "cherry-pick high quality (low default risk) borrowers, and force domestic banks to focus on serving customers with high risks, and as a result becomes nonprofit and less efficient, therefore decrease its competitiveness. Also, foreign banks tend to track rent-seeking behaviour and these make local banks less competitive" (Jeon et al., 2011).

Notwithstanding the fact that the practical observations on the impact of the entry of foreign banks on the performance of local banks is not certain, this issue has led to the publication of many single-country and cross-country papers.

Some of the papers which examined the effect of the entry of foreign banks on net interest margin include Barajas et al. (2000), Claessens et al. (2001), Dabla-Norris and Floerkmeier (2007), Poghosyan (2010), and Acheampong (2013). Also, some of the papers which examined the effect of the entry of foreign entry on competitiveness in the local banking sector include Dabla-Norris and Floerkemeiier (2007), Levy-Yeyati and Micco (2007), Schwaiger and Liebeg (2008) and Jeon et al. (2011).

The primary goal of this research is to examine the effect of the entry of foreign banks on the performance of local Jordanian banks in terms of their net interest margin and competitiveness during the period 2000-2010.

The contribution of this research does not stem from the development of original research methodology. On the contrary, and as implied above, the literature is quite clear regarding the measurement of competitiveness, determinants of net interest margin, and the impact of the entry foreign banks on local banks' performance.

The main contribution of the research stems from the fact that, as far as the researchers are aware, the impact of the entry foreign banks on competitiveness and net interest margin in the Jordanian banking sector has not been investigated. Indeed, this is important given that relative to the national economy, the size of banking sector in Jordan is large. For example, the ratio of the total licensed banks' assets to Gross Domestic Product (GDP) is equal to 179 percent (2012). Also, the ratio of private sector credit to GDP is equal to 72.0 percent (2012).

\section{The Data, Methodology and Empirical Results}

To identify the effect of the entry of foreign banks on the performance of the Jordanian banking sector in terms of net interest margin and competition, we include in the statistical analysis a total of twelve (12) Jordanian banks and five (5) non-Jordanian banks. The sample of Jordanian banks excludes the two Islamic banks and the Housing Bank for Trade and Finance (Note 2). The five (5) non-Jordanian banks are those banks whose branches were established in 2004/2005 or reflect some significant change (in number) in 2004/2005 (Note 3 ).

To assess the effect of foreign bank entry on the performance of Jordanian banks in terms of their net interest margin, we specify the regression equation as follows:

$$
\begin{gathered}
\text { IIM }_{i, t}=\beta_{1} \text { SIZE }_{i, t}+\beta_{2} \text { OVERH }_{i, t}+\beta_{3} C A P_{i, t}+\beta_{4} L_{O A N S}+\beta_{5} \text { RISK }_{i, t}+\beta_{6} \text { COMM }_{i, t}+\beta_{7} D M_{t} \\
+\beta_{8} \text { GROWTH }_{t}+\beta_{9} I N F_{t}+\varepsilon_{i, t}
\end{gathered}
$$

where both subscripts $\mathrm{i}$ and $\mathrm{t}$ indicate banks $(\mathrm{i}=1, \ldots, \mathrm{N})$ and Time $(\mathrm{t}=1, \ldots, \mathrm{T})$ respectively.

The net interest margin is the dependant variable and for the empirical analysis, we use the following measure: $\mathrm{NIM}=$ [Interest Income - Interest Expense $]$ / Total Assets. Also, the independent variables include the natural log of total asset (SIZE), total operating expense to total assets (OVERH), equity capital to total asset (CAP), total credit (loans) to total asset (LOANS), loan loss provisions to total credit (RISK), net commission income to total operating income (COMM), the growth rate in real GDP (GROWTH), and the rate of inflation (INF).

In addition, we include in the model a dummy variable (DUM) which is equivalent to zero during the time 2000-2005, and one during the period 2006-2010. This (dummy variable) is introduced to capture the impact of foreign banks entries on net interests' margin.

To inspect the effect of the entry of foreign banks and the competitive conditions that prevail in Jordanian banking sector, we measure the competitiveness in the banking sector in each of the two sub-periods; 2000-2005 and 2006-2010. If foreign banks have led to any change (increase) in the competitiveness level in the Jordanian banking sector, the second sub-period (during which foreign banks have become more involved in Jordanian economy) should reflect different results compared with the results of the first sub-period. We estimate for each of the two sub-periods the following: 


$$
\begin{aligned}
\operatorname{lnINTREV} V_{i, t}=\alpha_{0}+ & \alpha_{1} \ln \operatorname{PERS}_{i, t}+\alpha_{2} \ln \operatorname{INTEXP}_{i, t}+\alpha_{3} \ln \operatorname{OTHEREXP}_{i, t}+\alpha_{4} \ln C A P_{i, t} \\
& +\alpha_{5} \ln \operatorname{SIZE}_{i, t}+\alpha_{6} \operatorname{lnRISK_{i,t}}+\alpha_{7} \ln \ln \operatorname{SROWTH}_{t}+\varepsilon_{i t}
\end{aligned}
$$

where as above, both subscripts $i$ and $t$ indicate banks $(i=1, \ldots, N)$, time $(t=1, \ldots, T)$ respectively. $(\mathrm{Ln})$ is the natural logarithm of the operator.

The dependent variable is the ratio of bank interest revenues to the total assets (INTREV). The independent variables include the ratio of employees expense to total assets (PERS), interest expense to total deposits (INTEXP), other operating expenses to total assets (OTHEREXP), equity capital to total assets (CAP), total assets (SIZE), net credit to total assets (RISK), and real GDP growth rate (GROWTH).

Based on the above expression (2), the H-statistic is given by $H=\alpha_{1}+\alpha_{2}+\alpha_{3}$. In other words, the sum of these three coefficients indicates how bank interest revenue (INTREV) reacts to changes in the three input prices (PERS, INTEXP, and OTHEREXP). An important mark of the H-statistic is that it should be performed on banks which are in their long-run equilibrium condition. This can be tested by regressing return on assets (ROA), instead of bank interest revenue, on input prices. If the sum of the three costs' elasticities is equal to zero (E-statistic), this indicates long-run equilibrium.

To estimate the above models, the assessment technique that we intend to apply is the period seemingly unrelated regression (SUR), pooled estimated generalized least squares (EGLS). As far as the basic descriptive statistics for all the variables are concerned (not reported here), the most interesting observation concerns the measures of net interest margin. Indeed, its' mean values during the periods 2000-2005, and 2006-2010 are equal to 0.024 and 0.030 respectively. In other words, during the second sub-period (which includes foreign banks), the cost of financial intermediation is higher. As far as the regression results are concerned (Tables 1-2), the interesting results are threefold.

First, the dummy variable coefficient has a significant and positive relationship (Table 1). In other words, opposite to expectations, foreign banks in Jordan have not resulted in a decrease in the cost of financial intermediation. These observations are in line with the opponents of international bank entry who argue that the entry of foreign bank tends to "cherry-pick" high quality customers; and charges a high net interest margin than local bank, and follow rent-seeking behaviour.

Second, on average, the results indicate that the Jordanian banking system operates under monopolistic competition conditions. However, for the period 2000-2005 which includes only Jordanian banks, the value of the H-statistic is equal to 0.593 (Table 2). Similarly, for the period 2006-2010 which includes foreign banks, the value of the H-statistic is equal to 0.566 (Table 2). In other words, we can conclude that during the period 2000-2010, and following the entry of foreign banks, the competitive conditions in the Jordanian banking system have not witnessed any significant change. Relative to these observations, it is important note that the empirical results satisfy the long-run equilibrium conditions and these can be seen from the close-to-zero values of the E-statistics (Table 2).

Table 1. Regression results: net interest margin

\begin{tabular}{ll}
\hline Variable & Coefficient \\
\hline SIZE & $0.001^{*}$ \\
OVERH & $0.300^{*}$ \\
CAP & 0.007 \\
LOANS & $0.023^{*}$ \\
RISK & $-0.077^{*}$ \\
COMM & $-0.006^{*}$ \\
DUM & $0.004^{*}$ \\
GROWTH & -0.001 \\
INF & 0.001 \\
Adjusted ${ }^{2}$ & 0.856 \\
F-statistic & 104.606 \\
D-W Statistic & 2.003 \\
\hline
\end{tabular}

The dependent variable is the net interest margin. The independent variables are the natural logarithm of total assets (SIZE), total operating expense to total assets (OVERH), equity capital to total asset (CAP), total credit (loans) to total assets (LOANS), loan loss provisions to total credit (RISK), net commission income to total operating income(COMM), real GDP growth rate (GROWTH), and inflation rate (INF). The dummy variable (DUM) equals zero (2000-2005) and 1 (2006-2010). *T- test is significant at level $99 \%$. 
Table 2. Bank competition: estimation results

\begin{tabular}{ccc}
\hline & Jordanian Banks 2000-2005 & All Banks 2006-2010 \\
\hline Variable & Coefficient & Coefficient \\
PERS & $0.130^{*}$ & $0.154^{*}$ \\
INTEXP & $0.437^{*}$ & $0.385^{*}$ \\
OTHEREXP & 0.026 & 0.027 \\
CAP & $-0.067^{*}$ & -0.014 \\
SIZE & $-0.037^{*}$ & $-0.034^{*}$ \\
RISK & $0.165^{*}$ & $0.163^{*}$ \\
GROWTH & -0.052 & 0.013 \\
H-Statistic & 0.593 & 0.566 \\
Adjusted R & 0.829 & 0.809 \\
F-statistic & $166.145^{*}$ & $\left(574.672^{*}\right.$ \\
D-W Statistic & 1.888 & 1.664 \\
E-Statistic & 0.011 & -0.007
\end{tabular}

The dependent variable is the ratio of bank interest revenue to total assets. The independent variables include the ratio of personnel expense to total assets (PERS), interest expense to total deposits (INTEXP), other operating expenses to total assets (OTHEREXP), equity capital to total assets (CAP), total assets (SIZE), net loans to total assets (RISK), and the real GDP growth rate (GROWTH). *t-test is significant at the $99 \%$ level.

Finally, it would be useful to compare our estimates of competitiveness with other regional banking sectors. In Table 3, we report the H-statistics for a number of Arab (and Jordanian) banking sectors. Based on the reported results, it is stated that the "evidence suggests that banking sectors in MENA are best characterized as markets operating under monopolistic competition" (Anzoategui et al., 2010). Indeed, our estimated H-statistics are very similar to those reported by Anzoategui et al. (2010). For example, our measures of competitiveness (0.593 and 0.566 ) are comparable to the reported values of 0.593 and 0.480 about the banking sector in Jordan.

Table 3. Regional bank competition

\begin{tabular}{ccc}
\hline Country & $\mathbf{1 9 9 4 - 2 0 0 1}$ & $\mathbf{2 0 0 2 - 2 0 0 8}$ \\
\hline Algeria & 0.614 & 0.512 \\
Bahrain & 0.375 & 0.452 \\
Egypt & 0.746 & 0.625 \\
Jordan & 0.593 & 0.480 \\
Kuwait & 0.476 & 0.299 \\
Lebanon & 0.650 & 0.627 \\
Morocco & 0.277 & 0.503 \\
Oman & 0.822 & 0.678 \\
Qatar & 0.079 & 0.496 \\
S. Arabia & 0.756 & 0.605 \\
Tunisia & 0.578 & 0.376 \\
UAE & 0.882 & 0.723 \\
\hline
\end{tabular}

Source: Anzoategui et al. (2010) and Authors' calculations.

\section{Summary and Conclusions}

Proponents of the entry of foreign banks argue that foreign banks improve and enhance competition among local (host) banks, and this improves banks' efficiency and hence, leads to lower financial intermediation costs (net interest margins), and promotes the growth of economies by improving the efficiency of resource allocation. On the other hand, the opponents of the entry of foreign banks argue that the fact that that these foreign banks do not promote competitiveness in the host banking systems and tend to "cherry-pick" high quality borrowers and charges a greater net interest margin than local banks.

The economic importance of banks cannot be overstated in Jordan. These arguments are based on many obervations including the fact that the Jordanian banking sector is large comparative with the size of the local economy. This is why the aim of this study is to inspect whether or not foreign banks' entry has had any impact on the behaviour of bank spreads and the extent of competition. 
Based on the time period 2000-2010, and a total of twelve (12) Jordanian and five (5) non-Jordanian banks, a number of conclusions can be stated. First, while the overall mean cost of financial intermediation in Jordan is similar to that which prevails in other countries, it is reported that, opposite to expectations, foreign banks in Jordan have not resulted in a decrease in the cost of financial intermediation (net interest margin). Second, following the entry of foreign banks, the competitive conditions in the Jordanian banking system have not witnessed any significant change and remains, as has been, monopolistic competition.

The key policy implications of the results of this paper are straight forward. The Central Bank of Jordan (CBJ) should not assume that the sheer fact of opening-up the Jordanian banking sector to FDI in financial services would lead to improving the performance of local banks in terms of efficiency (net interest margin) and competitive conditions. Policy-makers must focus on "other determinants" including credit risk and loan loss provisioning.

\section{References}

Acheampong, N. (2013). The Effects of Foreign Bank Entry on the Financial Performance of Domestic-Owned Banks in Ghana. The International Journal of Business and Finance Research, 7, 93-104.

Barajas, A., Steiner, R., \& Salazar, N. (2000). The Impact of Liberalization and Foreign Investment in Columbia's Financial Sector. Journal of Development Economics, 63, 157-196.

Claessens, S., Demirguc-Kunt, A., \& Huizinga, H. (2001). How Does Foreign Entry Affect the Domestic Banking Market? Journal of Banking and Finance, 25, 891-911.

Cull, R., \& Peria, M. (2012). Foreign Bank Participation in Developing Countries: What Do We Know About the Drivers and Consequences of this Phenomenon? Policy Research Working Paper No. 5389, The World Bank.

Dabla-Norris, E., \& Floerkemeier, H. (2010). Bank Efficiency and Market Structure: What Determines Banking Spreads in Armenia? IMF Working Paper No. 134.

Demirguc-Kunt, A., \& Levine, R. (2008). Finance, Financial Sector Policies, and Long-Run Growth. Commission on Growth and Development Working Paper No 11.

Gurley, J., \& Shaw, E. (1967). Financial Structure and Economic Development. Economic Development and Cultural Change, 34, 333-346.

Jeon, B., Olivero, M., \& Wu, J. (2011). Do Foreign Banks Increase Competition? Evidence from Emerging Asian and Latin American Banking Markets. Journal of Banking and Finance, 35, 856-875.

Levy-Yeyati, E., \& Micco, A. (2007). Concentration and Foreign Penetration in Latin American Banking Sectors: Impact on Competition and Risk. Journal of Banking and Finance, 31, 1633-1647.

McKinnon, R. (1973). Money and Capital in Economic Development. Washington, DC: The Brooking Institution.

Poghosyan, T. (2010). Re-Examining the Impact of Foreign Bank Participation on Interest Margins in Emerging Markets. Emerging Markets Review, 11, 390-403.

Schwaiger, M., \& Liebeg, D. (2008). Determinants of Bank Interest Margins in Central and Eastern Europe. OENB Financial Stability Report, Austrian National Bank.

\section{Notes}

Note 1. For a good survey of the financial development \& economic growth literature, Demirguc-Kunt and Levine (2008).

Note 2. This exclusion is due to the fact that these banks in terms of their activities are different.

Note 3. This sample of non-Jordanian banks excludes only three (3) banks. These banks have been operating in Jordan albeit with a limited number of branches (1-2) since the 1970s.

\section{Copyrights}

Copyright for this article is retained by the author(s), with first publication rights granted to the journal.

This is an open-access article distributed under the terms and conditions of the Creative Commons Attribution license (http://creativecommons.org/licenses/by/3.0/). 